\title{
The importance of education and training for construction workers about requirements of the earthquake-safe house and retrofitting method using ferrocement layers
}

\author{
Fauzan $^{1,{ }^{*}}$, Sri Umiati ${ }^{1}$, Nidiasari ${ }^{1}$, Rinaldi E. P. ${ }^{1}$ and Jonathan $V$. O. ${ }^{1}$ \\ ${ }^{1}$ Civil Engineering Department, Andalas University, 25163 Limau Manis, Padang, Indonesia
}

\begin{abstract}
Construction workers play an important role in attaining a good construction and safe building. However, it has not been getting enough attention to the importance of worker's roles since it is assumed that engineer has already enough knowledge to control and supervise the construction workers. Based on the survey results, more than $95 \%$ of workers in West Sumatera have lack of knowledge about the earthquake-safe house requirements and retrofitting of damaged houses. In this study, the expert team of Andalas University conducted training for the construction workers in Padang City and Padang Pariaman District. The training provides all activities that support the whole construction process of the earthquake-safe house and the retrofitting method for unreinforced masonry houses using ferrocement layers, which is presented by slides presentation and practice on the field. The result of the training program shows that the knowledge of the construction workers on requirements of the earthquake-safe house and retrofitting method using ferrocement layer improved significantly. The construction workers understood how to build the earthquake-safe house and to retrofit the weak or damaged houses. This training program is an effective way in disaster risk reduction to prevent the damage to houses due to the earthquake.
\end{abstract}

\section{Introduction}

Indonesian houses are generally categorized as nonengineered buildings that are constructed without any proper structural analysis [1]. In general, the nonengineering buildings such as residential houses and schools are made of clay or mortar brick without any reinforcements, known as unreinforced masonry (URM) building [2].

Earthquakes that often occur in West Sumatra, especially in Padang City and Padang Pariaman District caused a lot of damage to buildings, especially on residential houses, starting from minor damage to severe damage. The biggest earthquake in West Sumatera hit Padang City and Padang Pariaman District on September $30^{\text {th }}, 2009$. This earthquake happened at 17:16:09 local time (10:16:09 GMT) with 7.6 moment magnitude $(\mathrm{Mw})$. The epicenter of the earthquake is $0.789^{\circ} \mathrm{S}$, $99.961^{\circ} \mathrm{E}$, with the depth of $80 \mathrm{~km}$ (Fig. 1) [3]. The earthquake was located in the subduction zone of IndoAustralian and Eurasia plates [4].

Based on the data from local government and National Agency for Disaster Management (BNPB) of Indonesia, the September $30^{\text {th }}$, 2009 earthquake caused fatalities and damaged buildings, around 1,195 deaths and significant damage to about 140,000 houses and 4,000 other buildings, especially in Padang City and Padang Pariaman District [5].

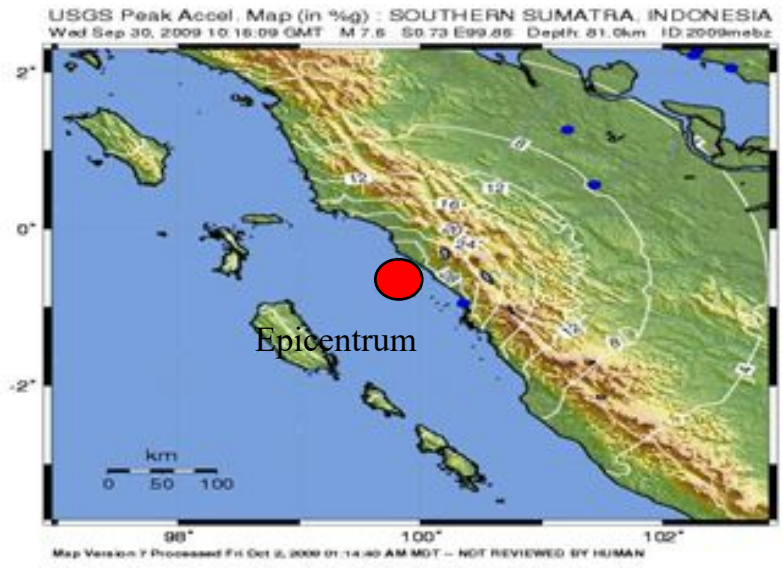

Fig. 1 West Sumatera earthquake on September $30^{\text {th }}, 2009$ (United States Geological Survey)

From field survey conducted by Andalas University and other universities in Padang City right after the September $30^{\text {th }}, 2009$ earthquake, it was found that almost all the damaged buildings were caused by the ignorance of earthquake-safe house standards [6]. The typical damages of houses obtained during the survey can be seen in Figs. 2 - 5.

The results of interview with householders, especially in Padang City and Padang Pariaman District show that almost all of the houses were constructed without any design and supervision from the engineer, which means 
that the houses were built based on the construction worker's experience and knowledge.

In West Sumatera, more than $95 \%$ of workers don't have enough knowledge about the earthquake-safe house requirements. In addition, the construction workers have not enough knowledge about the general requirement in constructing the earthquake-safe houses. So, the construction workers build the houses without following the requirement [6]. Moreover, the construction workers tend to finish the construction work as soon as possible in order to gain more profit, which makes the constructions even worse.

Earthquake risk reduction can be minimized by providing additional knowledge and skills to the construction workers to build an earthquake-safe house [7]. This study will examine the effect of training program for the construction workers about the requirements of the earthquake-safe house and retrofitting of the damaged house, as an action for disaster mitigation in West Sumatera, Indonesia.

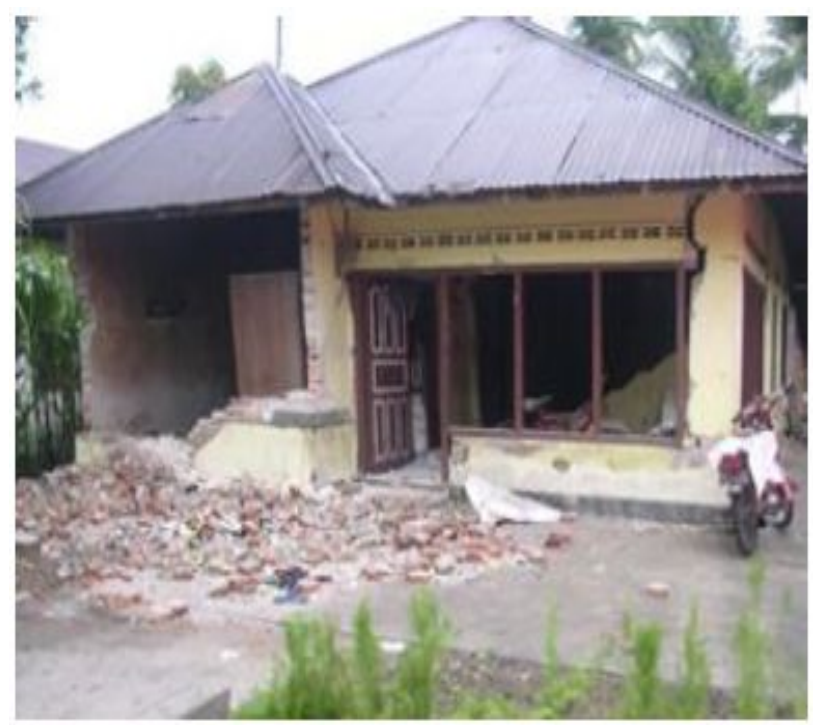

Fig. 2 Total damage of house after the September 30, 2009 earthquake [8]

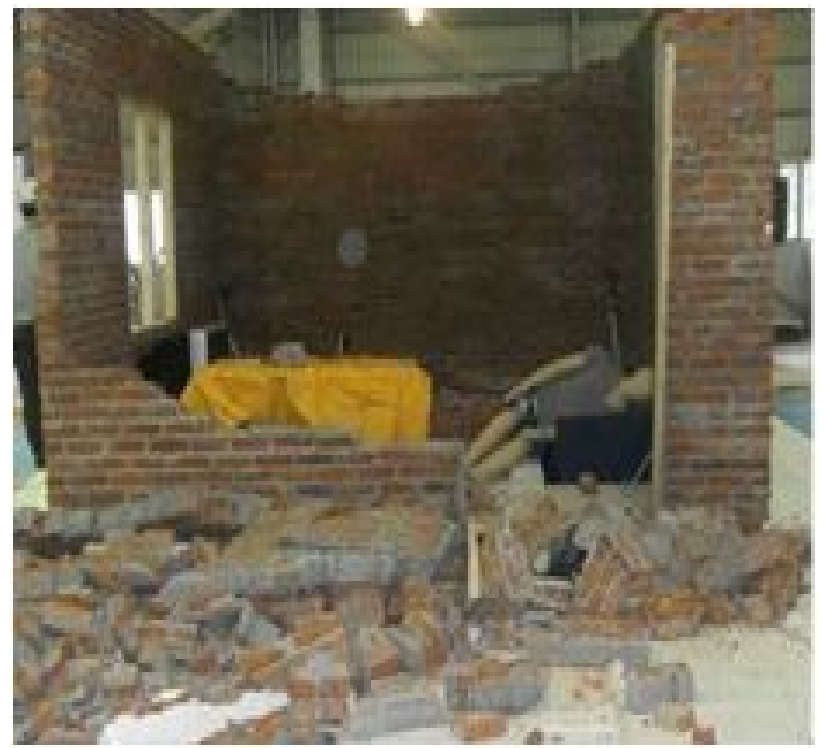

Fig. 3 Failure of clay brick wall [9]

\section{Training program}

In this program, training about the requirements of earthquake-safe house and retrofitting method using ferrocement layer for the construction workers was conducted in Padang city and Padang Pariaman District as a community service activity that supported by Institute for Research and Community Service of Andalas University.

The training provides all activities to support the whole construction process of the earthquake-safe house and the retrofitting of houses using ferrocement layers.

\subsection{The training subjects}

Subjects for training contain the method to build earthquake-safe houses and how to retrofit the unreinforced masonry houses made of clay or mortar brick using ferrocement layers. The training subjects consist of the requirements for foundation, steel reinforcement, anchor, roof truss and retrofitting method.

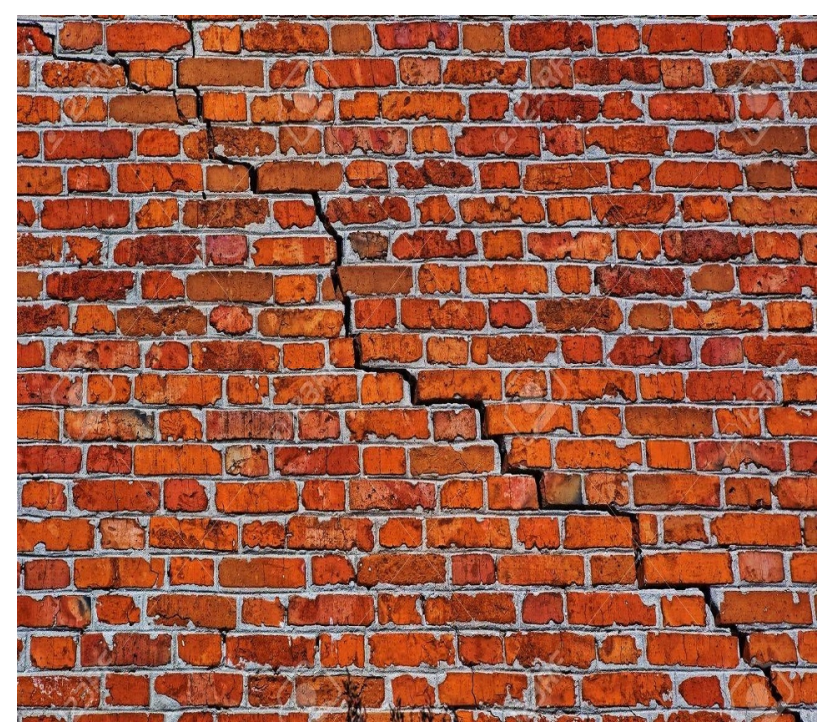

Fig. 4 Diagonal crack in wall [10]

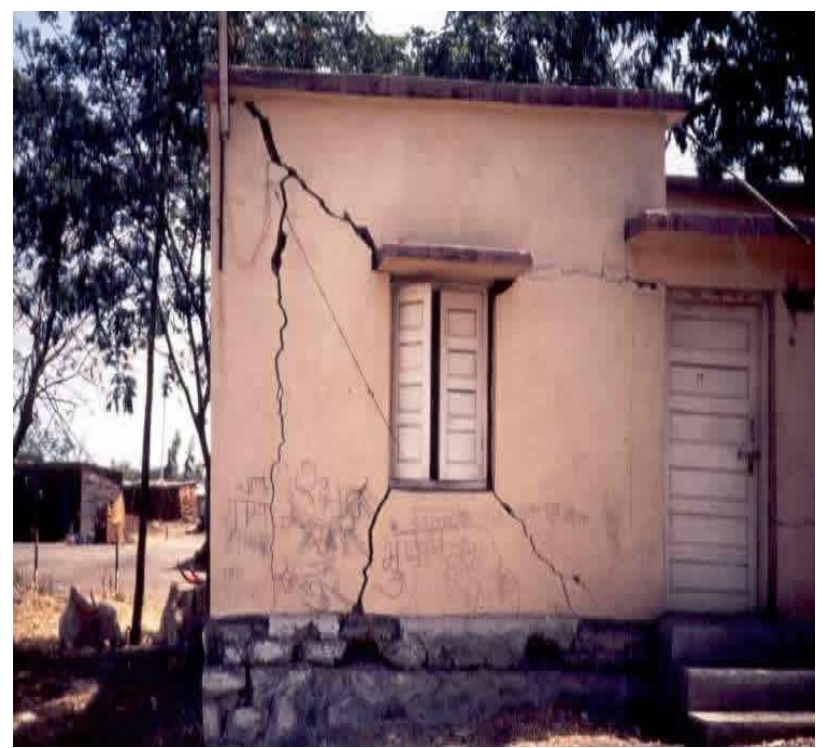

Fig. 5 Cracks of wall near opening [11] 


\subsubsection{Foundation}

Rubble stone should be neatly arranged with a good mortar. Tie beam must be anchored to the foundation every one meter using $\varnothing 10 \mathrm{~mm}$ steel bar. In addition, the tie beam must be cast with a good concrete. The detail of the foundation for the earthquake safe-house can be seen in Fig. 6.

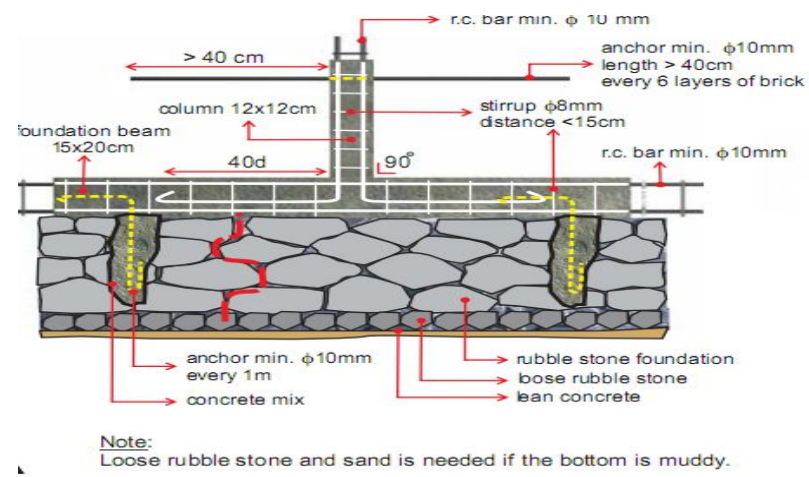

Fig. 6 Requirements for stone foundation [12]

\subsubsection{Bending of reinforcing bars}

The stirrup (shear reinforcing) bar should be bent with a length of 6D and a 45-degree angle, as shown in Fig. 7. The connection of reinforcing bar at the corner of beams should be bent around 40D.

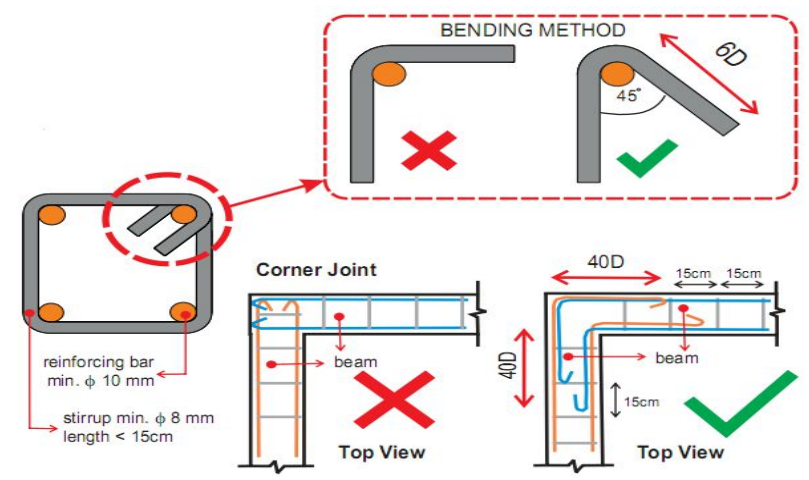

Fig. 7 Requirements for bending of reinforcing bars [12]

\subsubsection{Reinforcing bars at beam-column joint}

The construction workers need to tie the reinforcing bars properly and neatly. The reinforcing bar should be tied with three layers of iron wire with double knots. Beam and column reinforcing bars should use minimum $4 \varnothing 10$ $\mathrm{mm}$ steel bar. Stirrup (shear reinforcing) bar should have minimum $\varnothing 8 \mathrm{~mm}$ steel bar with the distance between the stirrups is less than $(<) 150 \mathrm{~mm}$. The detail of steel reinforcing bars at the beam-column joint is shown in Fig. 8.

\subsubsection{Column and wall anchor}

The anchor made of steel bar with $\emptyset 10 \mathrm{~mm}$ and length more than $40 \mathrm{~cm}$ should be installed to column in order to connect between column and wall. This anchor was installed in the column for every 6 layers of brick. Formwork must be erected full height on 3 sides of the column and it should be half of the column height for another side. Timber bracing $4 / 6 \mathrm{~cm}$ must be used to support the formwork for each side. Concrete should be placed on half of the column first, and then, continue for the other half of the column. The compaction of the concrete must be done with a steel $\operatorname{rod} \emptyset 12 \mathrm{~mm}$ and a rubber hammer to tap all sides of the formwork. The detail of column and wall anchor can be seen in Fig. 9.

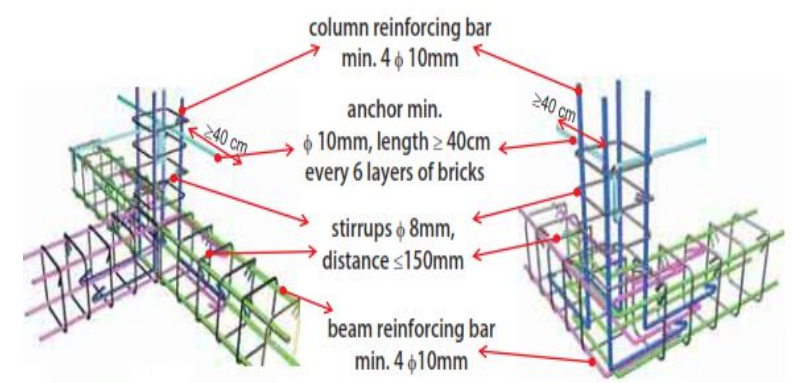

Fig. 8 Requirements for steel reinforcing bars detail at the beam-column joint [12]
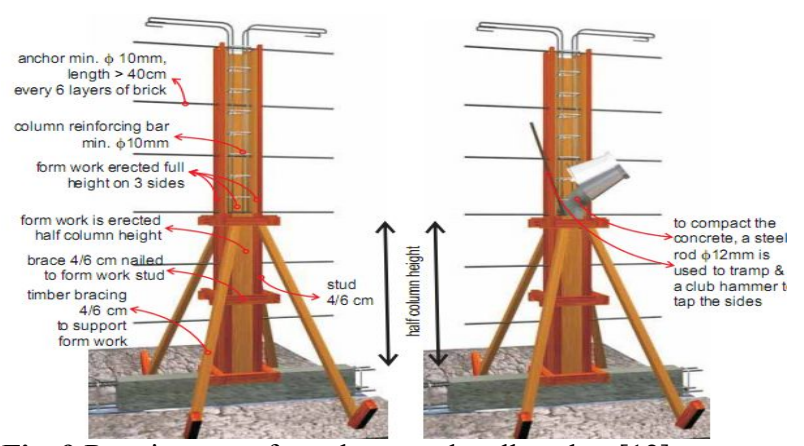

Fig. 9 Requirements for column and wall anchor [12]

\subsubsection{Timber roof truss}

Roof truss must be anchored to the structure. Timber bracing was used to tie the trusses $6 / 12 \mathrm{~cm}$. Steel clams must be used to tie the wood connections near the beam. Wooden pin and bolt min with $\varnothing 10 \mathrm{~mm}$ is used to connect between woods on the truss. The detail of the roof truss is shown in Fig. 10.

\subsubsection{Retrofitting of houses}

The method of retrofitting for houses using ferrocement layers was explained to the construction workers. The procedure of the retrofitting is as follows [12]:

- Remove the inner as well as the outer plaster of the wall $\pm 40 \mathrm{~cm}$ in the vertical and horizontal directions where the wire mesh will be installed. The inner and the outer plaster of walls junction also need to be removed.

- If there is crack, the cracks are sealed with cement \& sand mortar.

- If the existing mortar of the walls consists of lime \& sand or lime, red-brick powder \& sand, without cement, before strengthening with wire mesh, it is recommended to inject cement water into the mortar starting from the lower part of the wall. 


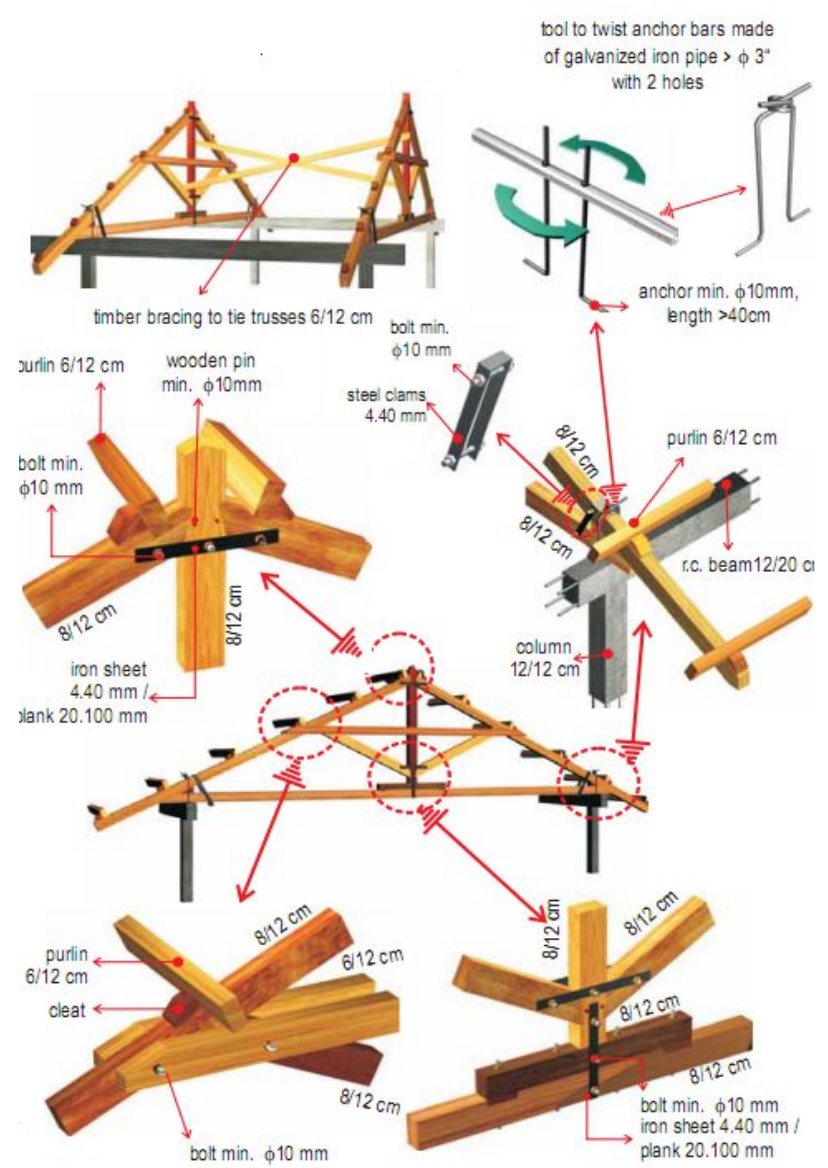

Fig. 10 Requirements for roof trusses detail [12]

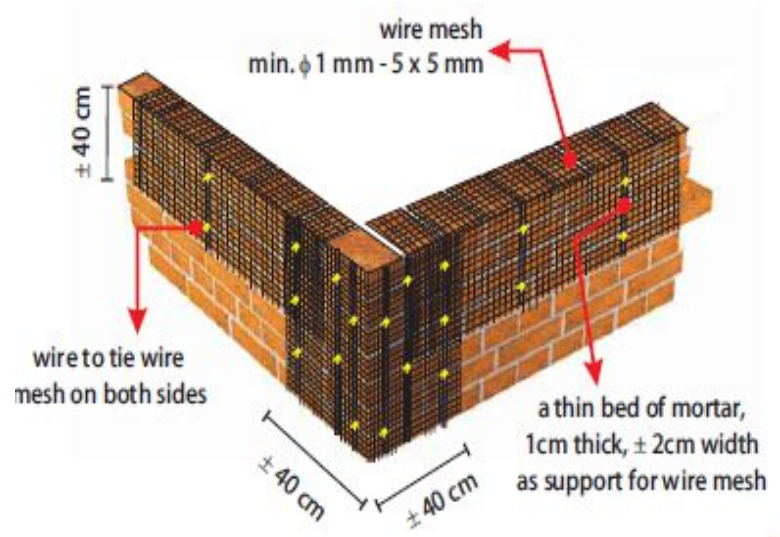

Fig. 11 Wall strengthening using wire mesh [12]

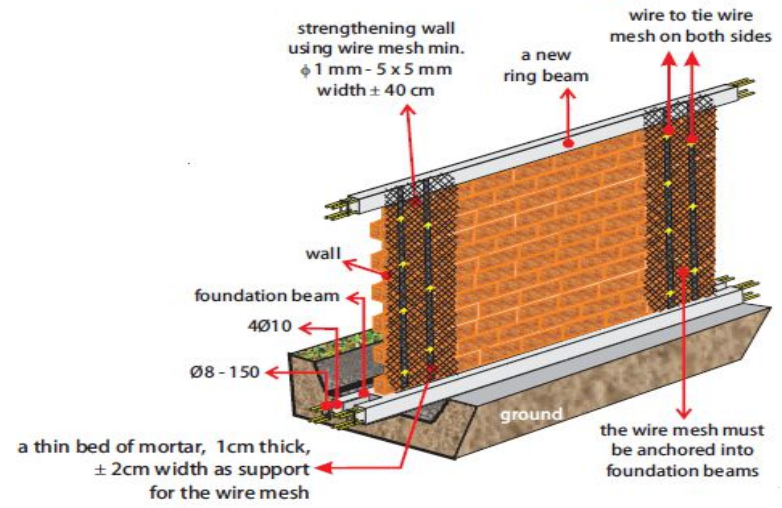

Fig. 12 Strengthening of the wall using bandaging system of wire mesh [12]
- Several thin beds of mortar, $1 \mathrm{~cm}$ thick, $2 \mathrm{~cm}$ width, and with spacing $\pm 10 \mathrm{~cm}$ must be made that serves as the support for the wire mesh (Fig. 11). Use $9 \mathrm{~mm}$ thick \& $2 \mathrm{~cm}$ width plywood strips as formwork to prepare the thin beds of mortar.

- Wire mesh on each side of the wall shall be tied. For the purpose, holes are drilled on the thin beds of mortar every $\pm 15-20 \mathrm{~cm}$.

- Built two foundation beams $15 \times 20 \mathrm{~cm}$ on each side at the lower parts of the walls below the floor. The wire mesh must be anchored into the foundation beam (Fig. 12).

- The foundation beam must be constructed first. After that replaster the walls where the wire mesh that already installed with mortar of cement \& sand.

\subsection{Method of training}

The training was conducted in Padang Sarai, Padang City and Kurai Taji, Padang Pariaman District by the expert team from Andalas University who understand the aspects of the earthquake-safe house and retrofitting method. The training was started with a pre-test to know the initial knowledge of the workers about the general requirement in earthquake-safe and retrofitting of houses. Then, the expert team explained the subjects of the training by the slides presentation. Furthermore, practice on the field was conducted on a targeted house. Finally, post-test was given to the workers after training.

\subsubsection{Pre-test}

The objective of giving a pre-test before training is to measure initial knowledge of construction workers so that the expert team who responsible in giving the subject could decide which part of the subject that needs deeper explanation and discussion. Series of questions are designed to explore the construction workers ability, which could give a general description on the weaknesses of the workers.

The questions in the pre-test covered the general requirements to build the earthquake-safe house, such as how to choose a good brick, and how to make a good concrete mix and detail of steel reinforcement.

\subsubsection{Presentation}

The expert team explains how to construct and retrofit a house based on the earthquake-safe house standard. The training was held for a full day in Padang Sarai, Padang City and Kurai Taji, Padang Pariaman District. In the presentation session, the construction workers were informed about general knowledge on the earthquake; how it affects the structural building, and all standards of the earthquake-safe house. Then, the expert team conducted some discussion about the slides presentation. After that, the training focused on the practical guidance of knowledge based on what they have got in the previous session. The presentation session can be seen in Figs. 13 - 14. 


\subsubsection{Practice on the field}

In this training, the construction workers conducted practice on the field on how to retrofit unreinforced masonry houses made of mortar brick without reinforcement using ferrocement layers. The expert team teaches the construction workers about how to mix the materials of concrete, the dimension of wire mesh used and how to install wire mesh to the wall on the unreinforced masonry houses. Figs. $15-16$ show the practice on retrofitting of houses using ferrocement layers in Padang City and Padang Pariaman District.

\subsubsection{Post-test}

A post-test was held after all of the training programs included the presentation, discussion and practice on the field are completed. The questions on the post-test are the same with those on the pre-test. The aim of the posttest is to measure the improvement of the construction worker's knowledge and awareness about the earthquake-safe house requirement. This could be measured by a score that obtained by each worker.

\section{Results and discussion}

\subsection{Results of training}

The results of the pre-test show that :

1. At the pre-test, generally, construction workers have a wrong perception about the general requirement in the construction process. For example, almost all workers assume that the meaning of 1:2:3 concrete mix is one sack of cement, two wagons of sand, and three wagons of gravel. In the discussion, they admitted that this assumption had been used since their first time working in the construction field and no one ever tried to teach them the right one.

2. The result of the test was not satisfied. From 40 workers, only 4 workers who could answer the test well, which means that only $10 \%$ of total workers who could answer the question well (more than $80 \%$ of the total question are correct). While, the others could only answer the questions around 50\% on average. Based on this data, it is found that the worker's knowledge about the requirement of the construction process is still low, even though they have been involved in the construction process for decades.

3. The workers do not know about the retrofitting of houses using ferrocement layers.

The results of the post-test show that :

1. After the training, the knowledge of the construction workers on requirements of the earthquake-safe house and retrofitting method using ferrocement layer improved significantly.

2. The construction workers understand how to build the earthquake-safe house and retrofit the weak or damaged houses.

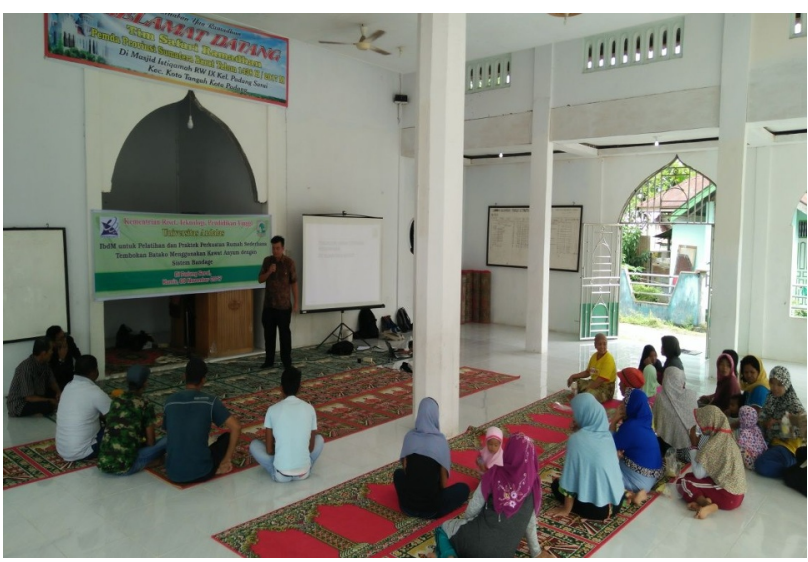

Fig. 13 Presentation of training subjects in Padang Sarai, Padang City

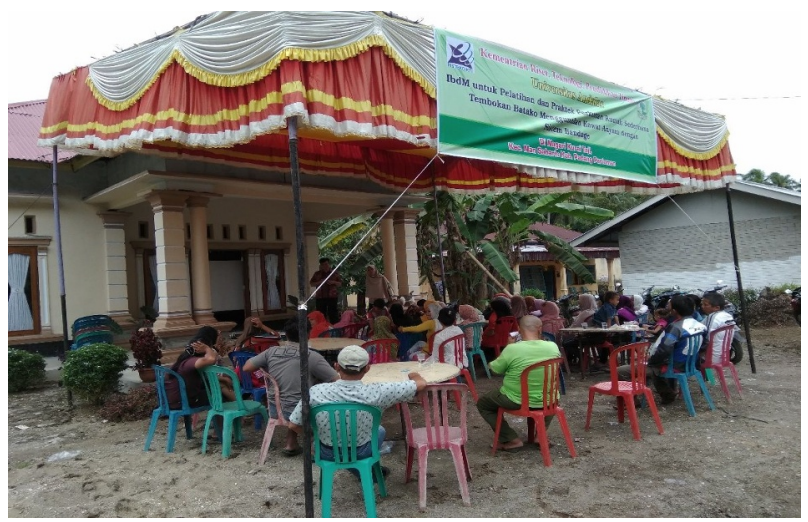

Fig. 14 Presentation of training subjects in Kurai Taji, Padang Pariaman District

\subsection{Discussion}

Based on the result of training, the following discussion points are obtained:

1. Construction workers clearly understand how to build the earthquake-safe house after the training.

2. If the construction workers are involved in a project where engineering is involved, then the supervisor process during the construction becomes easier.

3. Workers will have knowledge about the earthquake-safe house requirements. It will minimize the explanation from engineers during the construction process.

4. Workers who initially already know about the requirement are going to follow the standard willingly because they understand how important the build of houses based on the standard to reduce the victims of the earthquake.

5. Minimizing the error due to the ignorance of workers about the standard, thus optimize the working time.

6. Workers indirectly have become a media in socializing the information about the earthquakesafe house to the householders and the worker's community.

7. The increasing awareness of workers to follow the earthquake-safe house requirement will increase the number of the earthquake-safe house. 
8. The increase in the number of the earthquake-safe house is going to decrease the number of victims during the earthquake due to damaged building.

9. The retrofit of houses using ferrocement layers is simple that can be implemented easily to the local workers.

\section{Conclusions}

From this study, it can be concluded that:

1. The education of earthquake-safe house requirements and retrofitting method for weak or damaged houses is a must, not only for the engineers who design the building, but also for the workers who perform the construction.

2. After the training, the worker's knowledge about earthquake safe house improve significantly and can be implemented in their local area.

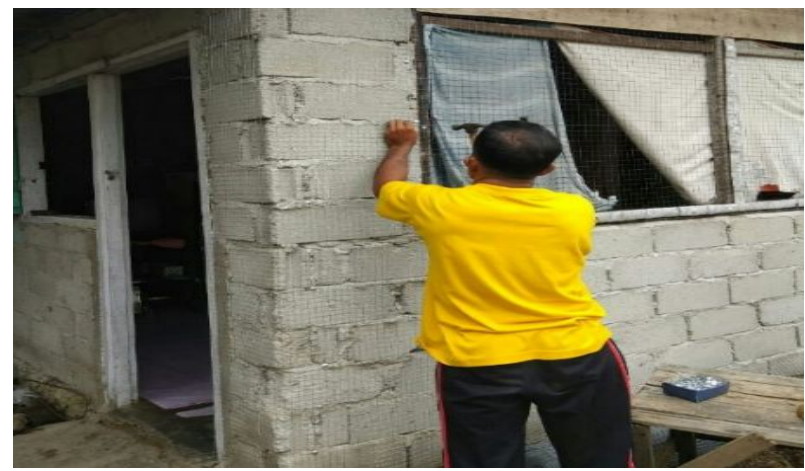

(a) The installing of wire mesh to the wall

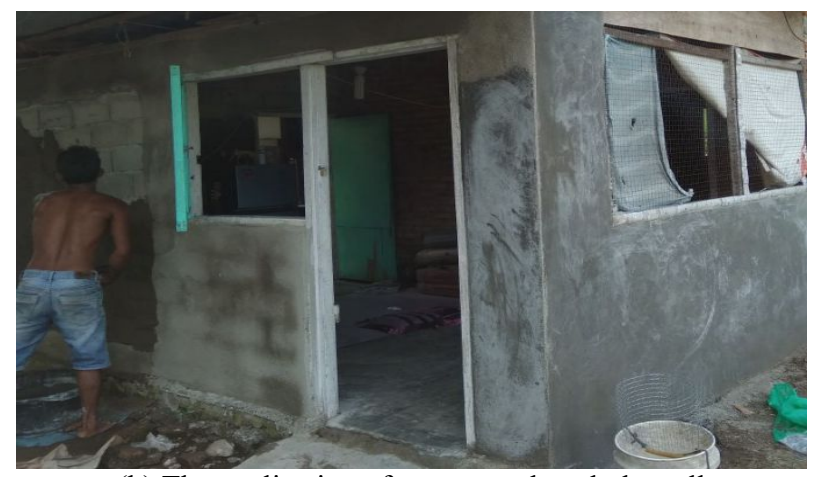

(b) The application of mortar to the whole wall

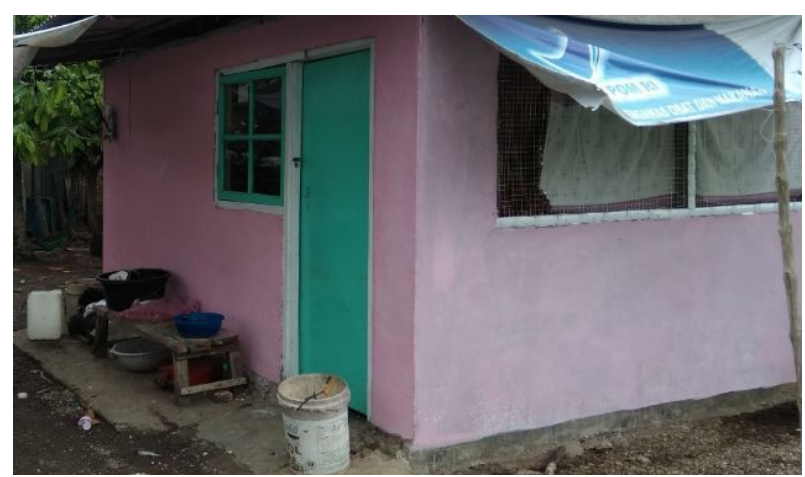

(c) The house after retrofitting

Fig. 15. The practice of house retrofitting by the workers in Padang Sarai, Padang City
3. The knowledge about retrofitting methods using ferrocement layers can be easily transferred to the local construction workers by field practice because the method is simple, low cost and fast in construction.

4. This training program is an effective way on disaster risk reduction to prevent casualties due to the damage of houses during the earthquake.

The authors would like to acknowledge the funding support provided by Andalas University, Padang, Indonesia.

\section{References}

1. F. A. Ismail, M. S. Asmirza, A. Hakam, Fauzan, "Ferrocement - Brick Sandwich Wall Applied to Non - Engineered Houses", International Journal of GEOMATE, vol. 14, issue 44 (2018).

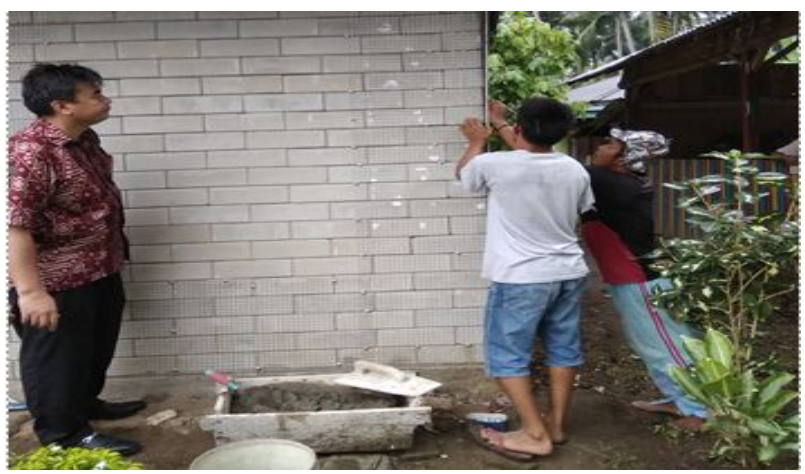

(a) The installing of wire mesh to the wall

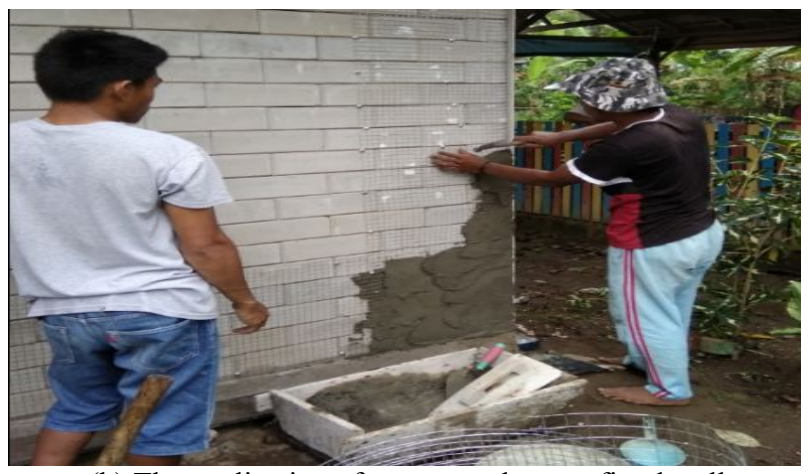

(b) The application of mortar to the retrofitted wall

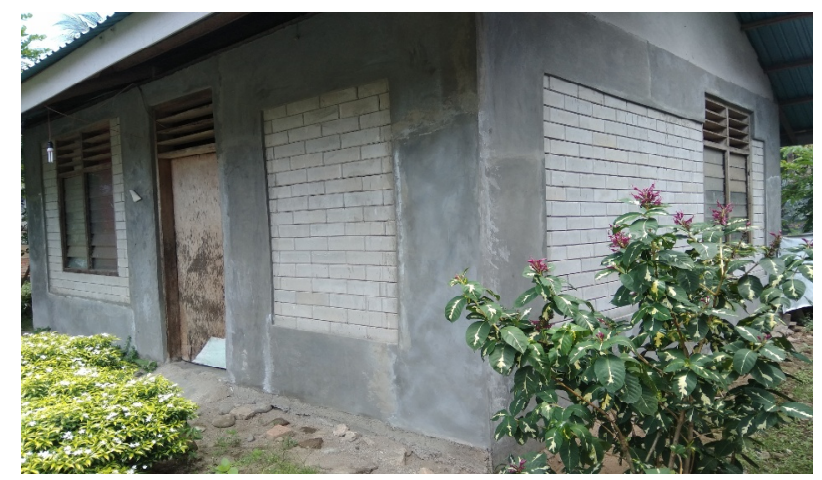

(c) The house after retrofitting

Fig. 16. The practice of house retrofitting by the workers in Kurai Taji, Padang Pariaman District. 
2. Boen. T, Arya A. S, and Ishiyama Y, Guidelines for Earthquake Resistant Non - Engineered Construction, United Nations Educational, Scientific and Cultural Organization (UNESCO), place de Fontenoy, Paris, (2014).

3. Map. (2018) United States Geological Survey, 2009 September 30 10:16:09 UTC. [Online]. Available:

http://earthquake.usgs.gov/earthquakes/recenteqsw w/Quakes/us2009mebz.php\#smap

4. D. Kusumastuti, M. Suarjana, I.W. Sengara, and Rildova. "Overview Of The West Sumatra Earthquake Of September 30, 2009, A Summary of MCEER Reconnaissance Efforts", Special Report MCEER-10-SP01, February (2010).

5. Coordinating Unit for Disaster Management Implementation, West Sumatera., (2009).

6. Earthquake Engineering Field Investigation (EEFI) Special Report, December (2009).

7. A. Hakam, Fauzan, F.A. Ismail, B. Istijono, "Capacity Building of Local Home Builders on Application of Earthquake Safe House for Disaster Risk Reduction", Annual Meeting of Indonesian Disaster Expert Association'4th, May, (2017).

8. Fauzan, F. A. Ismail, A. Hakam, S. H. Amalia, "Experimental Study on Masonry Building Strengthened with Ferrocement Layers", International Journal of GEOMATE, vol. 14, issue 45 (2018).

9. Boen T, "Brief Report of Shaking Table on Masonry Building Strengthened with Ferrocement Layer", 16th World Conference on Earthquake, Paper no. 1393 (2017).

10. (2018) Brick wall with Big Diagonal Cracks. [Online]. Available:

https://www.123rf.com/photo_14511448_brickwall-with-big-diagonal-crack. $\bar{h}$ tml

11. Housing Report "Unreinforced brick masonry building with reinforced concrete roof slab". (2018) World Housing Encyclopedia A Resource on Construction in Earthquake Regions. [Online]. Available: http://db.world-housing.net/pdf_view/21/

12. Boen. T, et al, Retrofitting Simples Buildings Damaged by Earthquake, 2nd ed., Jakarta, Indonesia: WSSI, (2010). 